\title{
Black Scab of Jojoba (Simmondsia chinensis) in Australia Caused by a Putative New Pathotype of Elsinoë australis
}

G. J. Ash and B. Stodart, E. H. Graham Centre for Agricultural Innovation (Department of Primary Industry and Charles Sturt University), School of Agricultural and Wine Sciences, P.O. Box 588 Wagga Wagga, NSW 2678, Australia; and J.-W. Hyun, Citrus Experiment Station, National Institute of Horticultural \& Herbal Science, R.D.A. Jeju, 697-943, Korea

\begin{abstract}
Ash, G. J., Stodart, B., and Hyun, J.-W. 2012. Black scab of jojoba (Simmondsia chinensis) in Australia caused by a putative new pathotype of Elsinoё australis. Plant Dis. 96:629-634.

A new disease of jojoba in Australia is described. We have demonstrated that this disease is caused by Elsinoe australis, a pathogen which is normally associated with citrus. This pathogen has not been found previously in Australia on citrus or any other crop. The fungus causes a scab on leaves and stems of jojoba and is widely distributed in

cates that it is closely related to the natsudaidai and the sweet orange pathotypes of E. australis, glasshouse and laboratory experiments demonstrate that it is not pathogenic to a range of citrus cultivars grown in Australia. The data indicate that the isolates from jojoba represent a new pathotype of E. australis.
\end{abstract} eastern Australia. Although molecular analysis of the pathogen indi-
Jojoba (Simmondsia chinensis (Link) Schneider, (Buxaceae)) is an evergreen shrub that is indigenous to Sonoran desert environments of southwestern United States and northwestern Mexico (10). The seed of the plant is harvested and crushed for its oil (a wax ester; 28), which is used largely in the cosmetic industry $(1,11)$. The wax ester has characteristics similar to sperm whale oil (17) and its tolerance to high heat and oxidizing conditions makes it suitable for synthetic oils used for high-temperature and highpressure industrial lubrication (27). In Australia, initial indications from trials conducted throughout the 1980s were that the crop had significant potential for growth in arid regions of the country $(17,18)$. However, some plantations were abandoned due to the great variation in yield obtained from seedling trees $(3,17)$. Cultivation of jojoba in Australia has had a resurgence since 1993 and the crop is currently grown in semiarid regions of Western Australia, South Australia, Queensland, and New South Wales (NSW) (3). Successful breeding programs conducted by the NSW Department of Primary Industries resulted in the development of three new clonal cultivars. The successful cultivars were more suited to the Australian environment because they flowered later, which prevented frost damage to developing flowers. Although the number of hectares planted to these clonal cultivars is presently small (circa $550 \mathrm{ha}$ ), there has been a slow but tangible expansion of the industry.

Jojoba is relatively disease-free in its natural habitat, although species of Pythium, Phytophthora, Fusarium, Verticillium, and Alternaria have been reported as pathogens of jojoba in a number of locations around the world (3). Additionally, several diseases of jojoba have been described in Australia (4). These include a fungal leaf spot caused by Pleospora herbarum (Pers.) Rabenh. (26), a collar rot caused by Fusarium oxysporum Schltdl. (2), and a bacterial spot caused by Burkholderia andropogonis (Smith) Gillis et al. (9). This latter disease is of importance only on seedlings, where it causes defoliation. Currently, collar rot is of the greatest concern to the industry because of its ability to rapidly kill mature plants.

Corresponding author: G. J. Ash, E-mail: gash@csu.edu.au

Accepted for publication 9 November 2011.

http://dx.doi.org/10.1094/PDIS-06-11-0465

(C) 2012 The American Phytopathological Society
In 2005-06, a black scab symptom was observed in many jojoba plantations in NSW and southern Queensland. The scab symptoms were visually similar to those caused by species of Elsino $\ddot{e}$ (Sphaceloma) on other plants. In Australia, Elsinö̈ ampelina Shear has been reported causing scab on grapevine (16); E. mangiferae Bitanc. \& Jenkins on mango (8); E. banksiae Pascoe \& Crous, E. leucospermi L. Swart et Crous, and E. proteae Crous \& L. Swart on Proteaceae (19); and E. fawcettii Bitanc. \& Jenkins on citrus $(21,23)$. To our knowledge, no scab disease has been reported on jojoba. The objectives of this study were to describe the scab disease of jojoba, identify the causal organism, and examine its potential host range.

\section{Materials and Methods}

Disease survey. A survey of scab disease of jojoba was undertaken in central NSW in June 2006 in three jojoba mature plantations growing 'Barindji'. Stem pieces (10 cm long, five per plant) were taken from 48 separate mature jojoba bushes at each location. All leaves were removed from the stems and scanned using a flatbed scanner (ScanJet 5200C; Hewlett Packard), and the percentage disease was determined using the software package "Assess: Image Analysis Software for Plant Disease Quantification" (American Phytopathological Society, St. Paul, MN).

Isolation of the causal organism via Koch's postulates. Young leaves with typical lesions were collected from jojoba at Hillston, NSW, Australia $\left(33.4^{\circ} \mathrm{S}, 145.9^{\circ} \mathrm{E}\right)$ in spring 2006 . The lesions were excised with a sterile scalpel, surface sterilized with $1.5 \%$ hypochlorite for $5 \mathrm{~min}$, washed in sterile deionized water, and plated on potato dextrose agar (PDA). The plates were incubated at $25^{\circ} \mathrm{C}$ for 2 weeks in the dark, after which distinctive dark erumpent colonies had grown. Six replicate, disease-free, glasshouse-grown jojoba (Barindji) were inoculated with small pieces of the advancing edge of fungal colonies grown on PDA plates, misted with deionized water, and covered for $24 \mathrm{~h}$ with a plastic bag. Newly developing leaves were examined after 3 weeks for symptom development. The fungus was reisolated from the lesions as above.

Light microscopy. Infected leaf and stem material of jojoba from the field were fixed in $50 \%$ formalin-acetic acid-alcohol, dehydrated through a graded ethanol series, and infiltrated with Leica HistoResin under a slight vacuum for a minimum of 2 days. The samples were placed in pharmaceutical gelatin capsules containing HistoResin and polymerized overnight at $60^{\circ} \mathrm{C}(6)$. They were then sectioned at $4 \mu \mathrm{m}$ using tungsten-carbide-tipped steel blades fitted to a motorized retraction microtome. The sections 
were viewed using a Nikon Eclipse 1000 microscope. Images were captured using a Nikon DXM1200 digital camera and the image software Nikon ACT-1 (version 2.20).

Single-spore protocol. The fungus was induced to sporulate in clarified Campbell's V8 juice (20\%). Sterilized medium $(20 \mathrm{ml})$ in a falcon tube (Bacto Laboratories P/L, Australia) was inoculated with three $2 \mathrm{~mm}^{2}$ pieces of culture from the leading edge of Sphaceloma colonies growing on PDA. The tubes were then placed in an orbital shaker for 10 days at $150 \mathrm{rpm}$ at $27^{\circ} \mathrm{C}$. The presence of spores was ascertained visually using a Nikon Eclipse 1000 microscope. Broth $(100 \mu \mathrm{l})$ was spread onto a fresh PDA plate and, following spore germination, an isolated colony was subcultured. A voucher culture of this single-spore isolate was lodged in Herbarium DAR under the accession number Herb DAR77387 (Department of Primary Industry NSW, Orange, NSW, Australia). All subsequent experiments were performed using this isolate.

Citrus inoculation. Bare-root seedlings of navel orange (Citrus sinensis 'Symons Sweet'), lemon ( $C$. limon (L.) Burm. F. 'Eureka'), rough lemon (C. jambhiri Lush.), mandarin (C. reticulata Blanco 'Dai Dai', 'Cleopatra', and 'Emperor'), and grapefruit (C. paradisi Macf. 'Duncan') were potted into commercial-grade potting mix and maintained in a glasshouse with an average temperature of $20^{\circ} \mathrm{C}$ and natural light. The seedlings were fertilized with quarter-strength Aquasol fertilizer solution (Hortico Aust. Pty. Ltd, Victoria; total N, 23\%; P, 4\%; K, $18 \%$; Zn, $0.05 \%$; Cu, 0.06\%; Mo, 0.0013\%; Fe, 0.06\%; and Bo, 0.01\%) every second week to promote new, lush growth.

In all experiments, jojoba leaves or plants were used as positive controls. Inoculations of citrus were undertaken in three ways. In the detached-leaf assay, young, fully expanded leaves were cut from the glasshouse-grown citrus seedlings, surface sterilized in $1 \%$ hypochlorite for $30 \mathrm{~s}$, and placed on $1.5 \%$ water agar in 90 $\mathrm{mm}$-diameter petri dishes. These were replicated four times for each citrus species or variety. The leaves were then inoculated with a 5-mm-diameter plug of the expanding edge of a culture of isolate DAR 77387 which had been grown on PDA. The plug was placed agar-face down on the leaves. An uninoculated agar plug acted as a negative control. These leaves were then incubated in a light incu- bator ( $12 \mathrm{~h}$ of light and $12 \mathrm{~h}$ of darkness) at $25^{\circ} \mathrm{C}$ for 14 days. The leaves were examined daily for symptoms of infection. After 14 days, the plugs were removed, the leaves were surface sterilized, and reisolation of the fungus from all inoculated leaves was attempted. This experiment was performed on two separate occasions.

In the case of whole-plant inoculations, spore suspensions of isolate DAR 77387 were produced as described above. A $1 \times 10^{8}$ spore suspension was used in experiments. One drop of Polysorbate 20 (Tween 20) was added to each of two 50-ml suspensions and the suspensions were sprayed onto the citrus seedlings in the glasshouse at $2.5 \mathrm{ml}$ of suspension per plant. Control plants were inoculated with sterile V8 juice (20\%) at the same rate. All plants were covered with clear plastic bags for $72 \mathrm{~h}$ and were then maintained in the glasshouse at ambient temperature and light for 4 weeks after inoculation for symptom expression.

For the detached-fruit assay, jojoba isolate DAR77387 was grown in liquid culture to induce sporulation. A $1 \times 10^{8}$ spore suspension was used in experiments. Fruit from a range of citrus varieties ('Imperial' and 'Daisy' mandarin; 'Marsh' grapefruit; 'Eureka' lemon; 'Tahiti' lime; sweet orange varieties 'Washington', 'Valencia', and 'Hamlin'; 'Natsudaidai' sour orange hybrid; and 'Faustrime' fingerlime hybrid) were obtained from the herbarium collection, Dareton, NSW. Jojoba leaves were included as positive controls. Fruit of each sample were placed on sterilized, moist filter paper within a plastic chamber and inoculated with a $10-\mu l$ drop of spore suspension. The container was then closed and incubated in a light incubator (12 h of light and $12 \mathrm{~h}$ of darkness) at $25^{\circ} \mathrm{C}$. Assessment for infection was made at 5, 10, and 15 days post inoculation. For each fruit variety, the experiment was conducted in triplicate, with the entire experiment repeated on consecutive days. Containers were randomized for placement in the incubator and rerandomized following score days. Samples were scored for presence or absence of lesions and surface growth.

Amplification and sequencing of partial rDNA region. Amplification of the complete internal transcribed spacer (ITS)1, $5.8 \mathrm{~S}$, and ITS2 region was achieved using primers ITS- 1 ( $5^{\prime}-$ TCCGTAGGTGAACCTGCGG-3') and ITS-4 (5'-TCCTCCGCT

Table 1. Blast scores resulting from a search of internal transcribed spacer (ITS) sequences with the GenBank database for sequence similarity to Elsinö̈ strain DAR77387 (596 bp)

\begin{tabular}{|c|c|c|c|c|c|c|}
\hline \multirow[b]{2}{*}{ Description $^{\text {a }}$} & \multirow[b]{2}{*}{ Origin } & \multirow[b]{2}{*}{$\begin{array}{c}\text { GenBank } \\
\text { ITS accession }\end{array}$} & \multicolumn{4}{|c|}{ BLAST scores } \\
\hline & & & $\begin{array}{c}\text { Maximum } \\
\text { score }\end{array}$ & $\begin{array}{c}\text { Query } \\
\text { coverage }(\%)\end{array}$ & $\begin{array}{c}E \\
\text { value }\end{array}$ & $\begin{array}{c}\text { Maximum } \\
\text { identity }(\%)\end{array}$ \\
\hline Elsinoë sp. strain Ea-J02* & Australia & GU126378.1 & 1,101 & 100 & 0 & 100 \\
\hline Elsinoë sp. strain Ea-J01* & Australia & GU126377.1 & 1,101 & 100 & 0 & 100 \\
\hline Elsinoë australis strain FZ-STM-CLB-1.4 & Brazil & FJ010318.2 & 1,101 & 100 & 0 & 100 \\
\hline E. australis strain VRG-BRT & Brazil & FJ010354.1 & 1,101 & 100 & 0 & 100 \\
\hline E. australis strain Ea-2 & Argentina & FJ010313.1 & 1,101 & 100 & 0 & 100 \\
\hline E. australis strain Ea-1 & Argentina & FJ010312.1 & 1,101 & 100 & 0 & 100 \\
\hline E. australis strain $\mathrm{Na}-1$ & South Korea & FJ010335.2 & 1,096 & 100 & 0 & 99 \\
\hline E. australis strain $\mathrm{KNa}-2$ & South Korea & FJ010327.2 & 1,096 & 100 & 0 & 99 \\
\hline E. australis strain 70212 & Argentina & FJ010291.2 & 1,096 & 100 & 0 & 99 \\
\hline E. australis strain $\mathrm{KNa}-5$ & South Korea & FJ010328.2 & 1,090 & 100 & 0 & 99 \\
\hline E. australis & $\ldots$ & $\mathrm{U} 28057.1$ & 1,090 & 100 & 0 & 99 \\
\hline E. ampelina isolate EAMI-1 & United States & AY826762.1 & 793 & 100 & 0 & 90 \\
\hline E. proteae strain STE-U 1349 & South Africa & AF097578.1 & 767 & 98 & 0 & 90 \\
\hline Sphaceloma manihoticola & Colombia & AY739019.1 & 760 & 98 & 0 & 90 \\
\hline E. banksiae strain DAR 50126 & Australia & AF227197.1 & 739 & 91 & 0 & 91 \\
\hline E. banksiae VPRI 21100 & Australia & AF097572.1 & 736 & 96 & 0 & 89 \\
\hline S. protearum strain STE-U 2034 & Zimbabwe & AF131081.1 & 717 & 92 & 0 & 90 \\
\hline E. leucospermi strain STE-U 2039 & Zimbabwe & AF131086.1 & 715 & 92 & 0 & 90 \\
\hline E. fawcettii strain STE-U 1609 & South Africa & AF097577.1 & 710 & 91 & 0 & 90 \\
\hline S. protearum strain STE-U 2035 & Zimbabwe & AF131082.1 & 706 & 95 & 0 & 88 \\
\hline E. leucospermi strain STE-U 2040 & Zimbabwe & AF131087.1 & 691 & 95 & 0 & 88 \\
\hline S. protearum strain STE-U 2038 & Zimbabwe & AF131085.1 & 688 & 92 & 0 & 89 \\
\hline S. fawcettii & $\ldots$ & U28059.1 & 664 & 96 & 0 & 98 \\
\hline E. fawcettii & $\ldots$ & U28058.1 & 664 & 96 & 0 & 98 \\
\hline E. leucospermi strain STE-U 2043 & South Africa & AF131090.1 & 660 & 91 & 0 & 88 \\
\hline E. leucospermi strain STE-U 2033 & South Africa & AF131080.1 & 654 & 94 & 0 & 87 \\
\hline
\end{tabular}

a Isolates marked with an asterisk (*) were isolated from jojoba by us. 
TATTGATATGC-3') (24) for three Elsino $\ddot{e}$ isolates from jojoba (DAR77387, Ea-J01, and Ea-J02). Reactions (15 $\mu \mathrm{l})$ consisted of $1 \times$ buffer (Bioline, Alexandria, NSW Australia), $0.2 \mathrm{mM}$ each dNTP, $2.5 \mathrm{mM} \mathrm{MgCl} 2,0.25 \mu \mathrm{M}$ each primer, 1 unit of BioTaq DNA polymerase (Bioline), and approximately $20 \mathrm{ng}$ template DNA. Amplifications were performed on a Hybaid PCR Express thermal cycler, with initial denaturing at $95^{\circ} \mathrm{C}$ for $3 \mathrm{~min}$ followed by 35 cycles of $94^{\circ} \mathrm{C}$ for $45 \mathrm{~s}, 56^{\circ} \mathrm{C}$ for $45 \mathrm{~s}$, and $72^{\circ} \mathrm{C}$ for $1 \mathrm{~min}$ $30 \mathrm{~s}$. A final elongation step of $72^{\circ} \mathrm{C}$ for 7 min was used.

Amplicons were purified using the Promega Wizard spin kit following the manufacturer's directions. Purified products were sequenced in duplicate at the Australian Genome Research Facility utilizing an AB3730xl sequencer, using the forward and reverse primers for each region examined, in separate reactions. Alignments to Elsinö̈ sequences obtained from GenBank and, specifically, to E. australis sequences obtained from J. W. Hyun were performed using ClustalW (22). Phylogenies were constructed following the Tamura-Nei model (20). Consensus neighbor-joining trees were generated following 1,000 bootstrap replicates. All analyses were performed with MEGA version 3.1 (15). The sequences of the isolates were lodged in GenBank (Table 1).

Amplification with species-specific primers. The species-specific primers of Hyun et al. (12) were used to further characterize the isolates of Elsinoe from jojoba. Primers Eaut1 and 5 along with EaNat1 were utilized. Reactions $(20 \mu \mathrm{l})$ consisted of $1 \times$ buffer (Bioline), $0.2 \mathrm{mM}$ each dNTP, $1.5 \mathrm{mM} \mathrm{MgCl}_{2}, 0.5 \mu \mathrm{M}$ each primer, 0.5 units BioTaq DNA polymerase (Bioline), and approximately $5 \mathrm{ng}$ of template DNA. Cycling was performed using $95^{\circ} \mathrm{C}$ for $2 \mathrm{~min}$; followed by 30 cycles of $94^{\circ} \mathrm{C}$ for $45 \mathrm{~s}$, either $50^{\circ} \mathrm{C}$ (Eaut5) or $55^{\circ} \mathrm{C}$ (Eaut1 and EaNat1) for $45 \mathrm{~s}$, and $72^{\circ} \mathrm{C}$ for $1 \mathrm{~min}$; and a final elongation of $72^{\circ} \mathrm{C}$ for $5 \mathrm{~min}$. Amplicons were separated by gel electrophoresis and visualized by staining with ethidium bromide.

Random amplified polymorphic DNA analysis of Elsinö̈ isolates. In all, 17 isolates of Elsinö̈ from jojoba were examined for genetic diversity using random amplified polymorphic DNA (RAPD) primers OPX-8, OPX-12, and OPX-17 identified by Hyun et al. (12), and compared with 6 Elsinoë isolates from citrus $(E$. australis strains Ea-2, Ea-4, VRG-BRT, 70212, FZ-STM-CL-1.4, and 70041)(13). Reactions (20 $\mu$ l) consisted of $1 \times$ buffer (Bioline), $0.2 \mathrm{mM}$ each dNTP, $2.5 \mathrm{mM} \mathrm{MgCl} 2,0.5 \mu \mathrm{M}$ each primer, 1 unit of BioTaq DNA polymerase (Bioline), and $5 \mathrm{ng}$ of template DNA. Cycling conditions consisted of an initial denaturing step of $95^{\circ} \mathrm{C}$ for $3 \mathrm{~min}$; followed by 35 cycles of $94^{\circ} \mathrm{C}$ for $45 \mathrm{~s}, 40^{\circ} \mathrm{C}$ for $45 \mathrm{~s}$, and $72^{\circ} \mathrm{C}$ for $80 \mathrm{~s}$; and a final elongations step of $72^{\circ} \mathrm{C}$ for $7 \mathrm{~min}$. Amplicons were separated by gel electrophoresis and visualized using ethidium bromide.

\section{Results}

Disease survey. The disease occurred in all regions of NSW which were surveyed and has been observed on jojoba in Queensland. The level of the disease was low at all locations, with the severity ranging from 1.0 to $2.4 \%$ of the leaf area. Although the severity was low, the incidence was high (over $80 \%$ in some locations). Anecdotal reports indicate that the disease severity increases after summer storms. In the field, black scab lesions occurred on the leaf, calyx, and young stems of jojoba (Fig. 1A-C). Lesions may coalesce when large numbers occur on one leaf, leading to senescence of the leaf and leaf drop, or they may affect the ability of the flower to open.

Isolation of the causal organism via Koch's postulates. Distinctive scab lesions developed on the leaves of inoculated plants after 3 weeks in the glasshouse. The fungus was reisolated from all inoculated plants, thus satisfying Koch's postulates. The fungus was identified as a Sphaceloma sp. by Dr. Michael Priest (Department of Primary Industry NSW, Orange, NSW, Australia). Spores produced in liquid culture conformed to the description of Sphaceloma sp. (Fig. 1D). Lesions were found on both abaxial and adaxial surfaces of the leaves. These were circular and largely discrete. Lesion diameter varied from less than $0.5 \mathrm{~mm}$ to over 2 $\mathrm{mm}$ in diameter. The margin was often black to brown and lesions continued through the leaf lamina under some circumstances.

Light microscopy. Microscopic examination of the transverse sections of leaf lesions clearly showed the production of cork layers between the lesion and the apparently healthy material (Fig. 1E) similar to those described by Kim et al. (14) in the E. fawcettii-citrus pathosystem. It is thought that this layer deprives the pathogen of nutrients, slowing the infection and, in some cases, causing the lesion to fall from the leaves (14). In jojoba, the lesion remains intact. Severely affected leaves often dehisce and fall from the plant. In the transverse longitudinal sections of the stem, sporulating lesions were found in the leaf axes (Fig. 1F). Once again, the fungal tissue was surrounded by a cork layer but large numbers of spores were being produced from these lesions.

Citrus inoculation. Repeated inoculations with the jojoba isolates on detached leaves and potted plants of a range of citrus varieties failed to produce any symptoms. Simultaneous inoculation of jojoba plants or leaves produced the typical symptoms. Although no symptoms were produced on detached leaves, Elsinö̈ spp. were reisolated from mandarin Cleopatra (on two separate occasions) and from the grapefruit Duncan (once).

Inoculation of detached fruit representing a range of citrus varieties failed to produce lesions on any sample, whereas jojoba leaves inoculated as controls displayed symptoms typical of jojoba black scab. Surface growth was evident on several varieties but failed to produce lesions on fruit skin. Elsinö̈ spp. were not reisolated from representative citrus fruit samples.

Amplification and sequencing of partial rDNA region. The ITS sequences from the three representative isolates of Elsinoë spp. from jojoba were identical and were also identical to four isolates of E. australis (Fig. 2, Table 1). The E. australis isolates all grouped in the same clade and this grouping was well supported by bootstrap analysis. This clade was also clearly distinct from the isolates of E. fawcettii and other Elsinö̈ spp. found in Australia and elsewhere.

Amplification with species-specific primers. The separation of the isolates was further supported by the species-specific primers (Eaut-1 and Eaut-5) for E. australis, with the isolates from jojoba producing the expected fragment sizes of approximately $450 \mathrm{bp}$ (data not shown) and $360 \mathrm{bp}$, respectively (Fig. 3). DNA from the jojoba isolates was also amplified by the natsudaidai-specific primer EaNat-1, giving the expected fragment size of approximately 580 bp (Fig. 3).

RAPD analysis of Elsino $\ddot{\boldsymbol{e}}$ isolates. The OPX-8 and OPX-12 RAPD primers indicated that there was polymorphism between the E. australis isolates from jojoba and those from citrus, with little polymorphism between jojoba isolates (Fig. 4). Primer OPX-17 failed to amplify consistently across all the DNA samples examined from jojoba and citrus.

\section{Discussion}

Black scab is a newly reported disease of jojoba, caused by a species of Elsinoë. Pathogenicity of the fungus to jojoba (Barjindi) was confirmed in laboratory tests, and microscopic examination of sections of lesions on stems and leaves of jojoba confirmed the presence of the fungus. Although this disease has not been previously described, field observations show that the fungus is widespread throughout jojoba plantations in southeastern Australia, with the majority of leaves being affected in some locations. Although the average disease severity was low, the disease appeared to cause leaf drop and may hinder flower opening when sepals are infected. It is considered that the disease would not warrant management in the dry conditions under which the crop is grown in NSW, although it could have the potential to decrease jojoba yields under favorable environmental conditions, especially in southern Queensland. In Queensland, there is a predominance of summer rainfall and high humidity when active growth of the crop occurs.

Several authors $(12,14)$ have reported using the technique of Whiteside (25) to produce conidia of Sphaceloma spp.; however, we were not able to induce sporulation using this technique. How- 

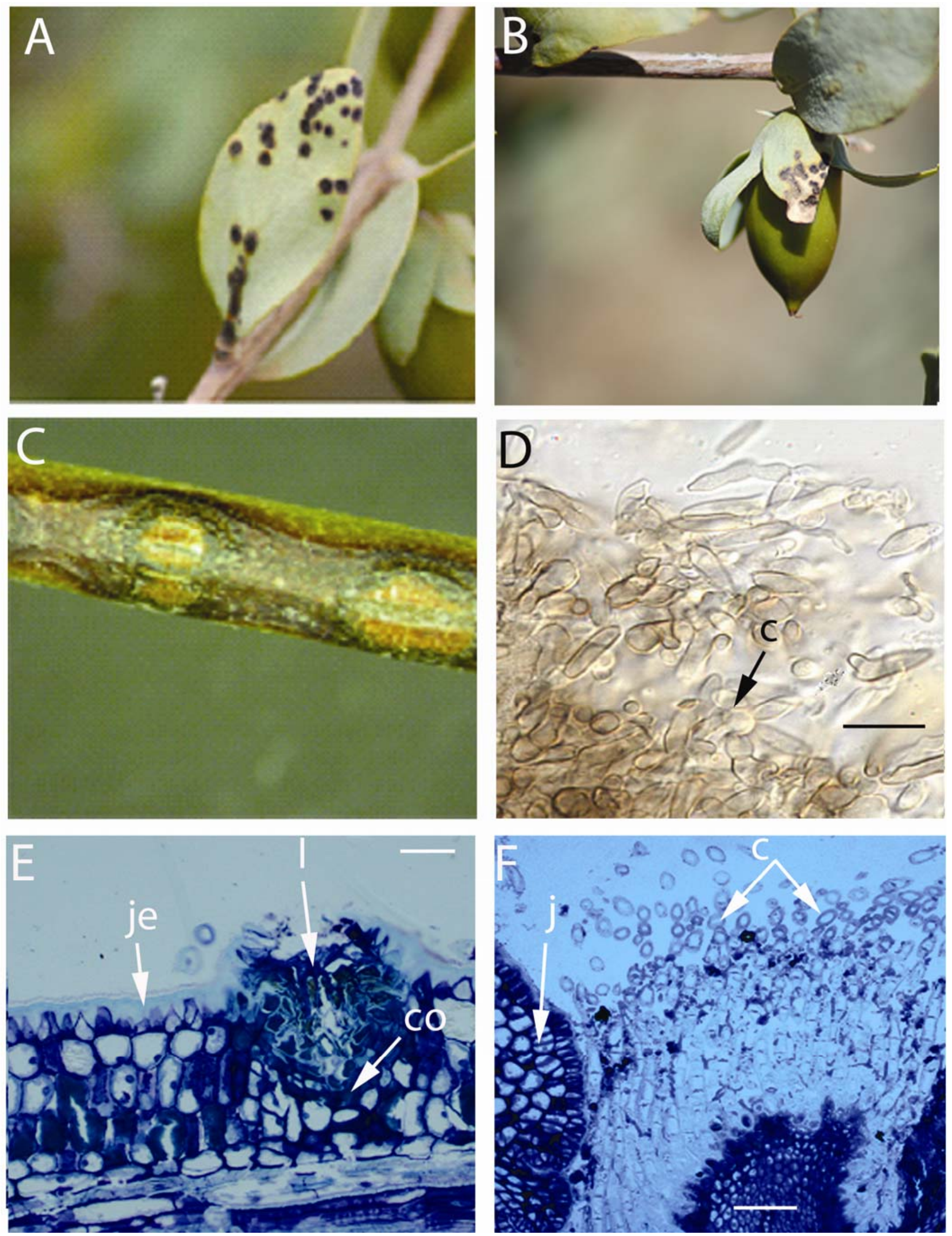

Fig. 1. Symptoms of black scab of jojoba on A, leaves; B, calyx; and C, stems. D, Conidia of Sphaceloma produced in liquid culture; $\mathbf{C}=$ conidium, bar $=10 \mu \mathrm{m}$. E, Transverse sections of a scab on a leaf showing cork layers (co) and thick jojoba epidermis (je), bar $=50 \mu \mathrm{m}$. F, Transverse longitudinal section of a stem showing sporulation in a leaf axis; $\mathrm{c}=$ conidium, $\mathrm{j}=$ jojoba tissue $\mathrm{I}=$ fungal lesion, bar $=50 \mu \mathrm{m}$. 
ever, a modified technique using $20 \%$ V8 juice agar was developed. The resultant conidia were used in the inoculation of detached leaves, detached citrus fruit, and seedlings of citrus and jojoba. This technique also allowed the production of single-spore isolates which were used in the molecular characterization of the fungus.

Sequencing of several isolates of the jojoba fungus has led to the conclusion that the fungus is closely related to E. australis (anamorph Sphaceloma australis Bitanc. \& Jenkins), a fungus which has not been identified previously in Australia. E. australis has been reported to cause sweet orange scab, with the teleomorph being found only in Brazil $(5,7)$. E. australis is on the Plant Health Australia watch list as a serious threat to the Australian citrus industry. In Australia, several species of Elsinoë and Sphaceloma

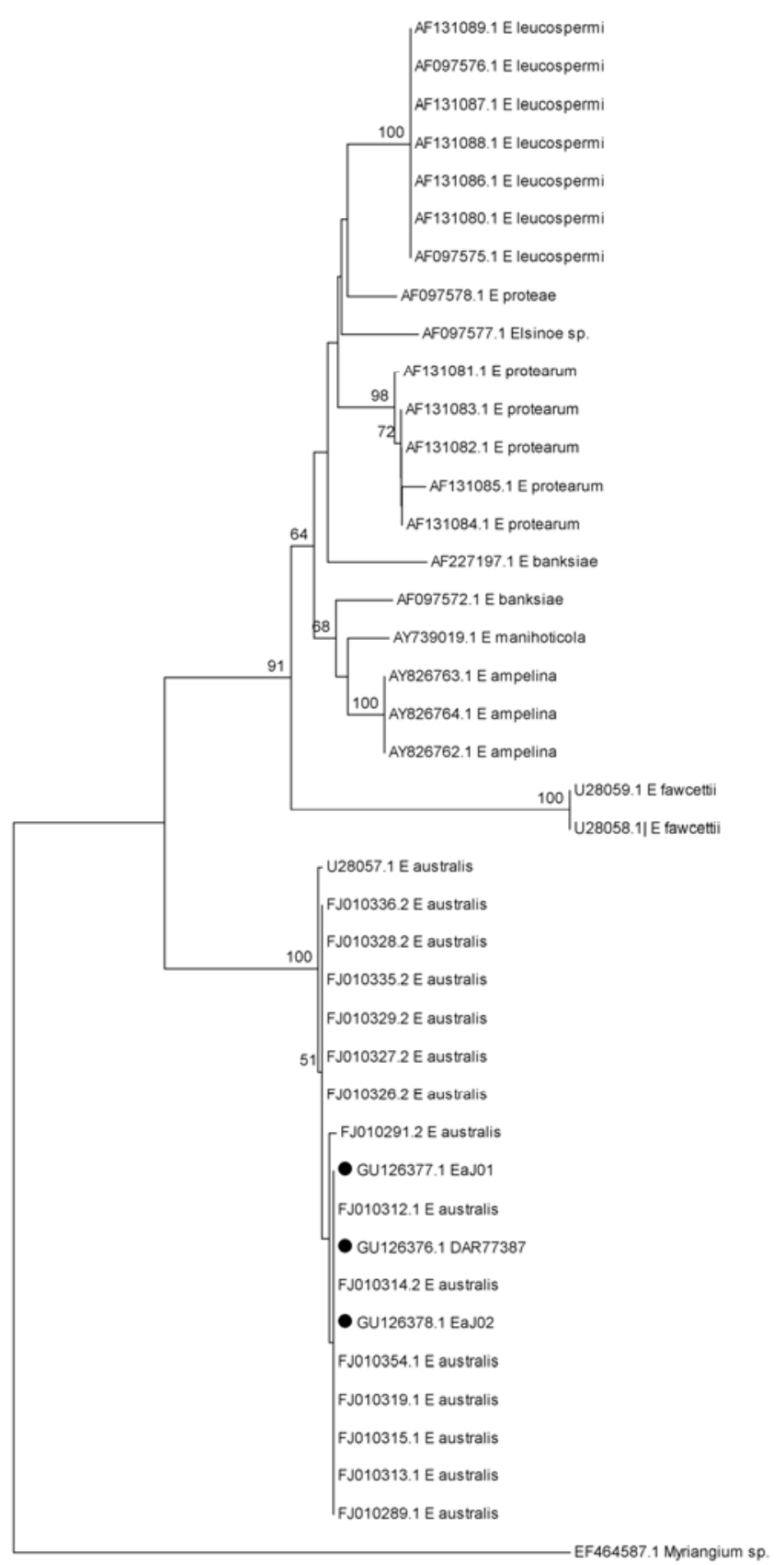

$$
0.02
$$

Fig. 2. Consensus neighbor-joining tree based on the alignment of 441 sequence sites of the rDNA internal transcribed spacer (ITS) region from Elsinoë spp. Percentage values for bootstrap replicate support are provided above each node; - denotes ITS sequences from Elsinoë from jojoba.

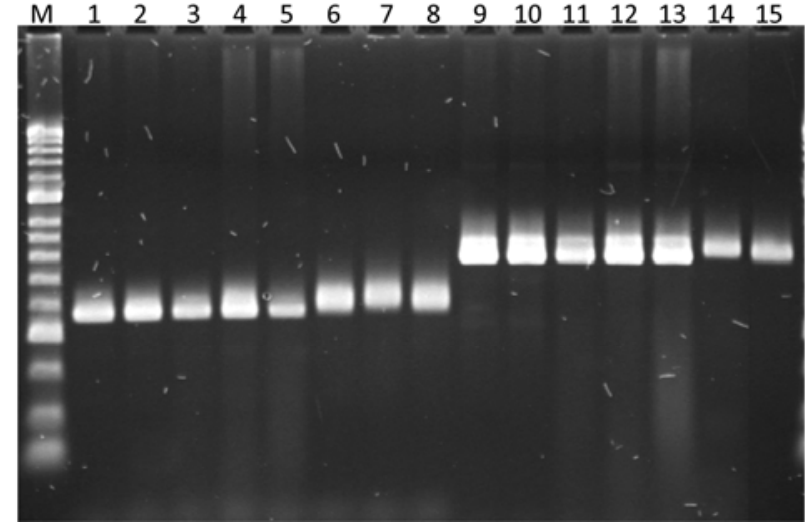

Fig. 3. Amplification of Elsinoë australis isolates obtained from jojoba with speciesspecific primers designed by Hyun et al. All isolates amplified with the $E$. australisspecific primer Eaut-5 displaying the reported fragment size of approximately 360 bp (lanes 1-8); the majority of jojoba isolates were amplified with the Natsudaidai pathotype-specific primer set EaNat1 displaying the expected fragment size of approximately 580 bp (lanes 9-16). M = BioLine Hyperladder II.

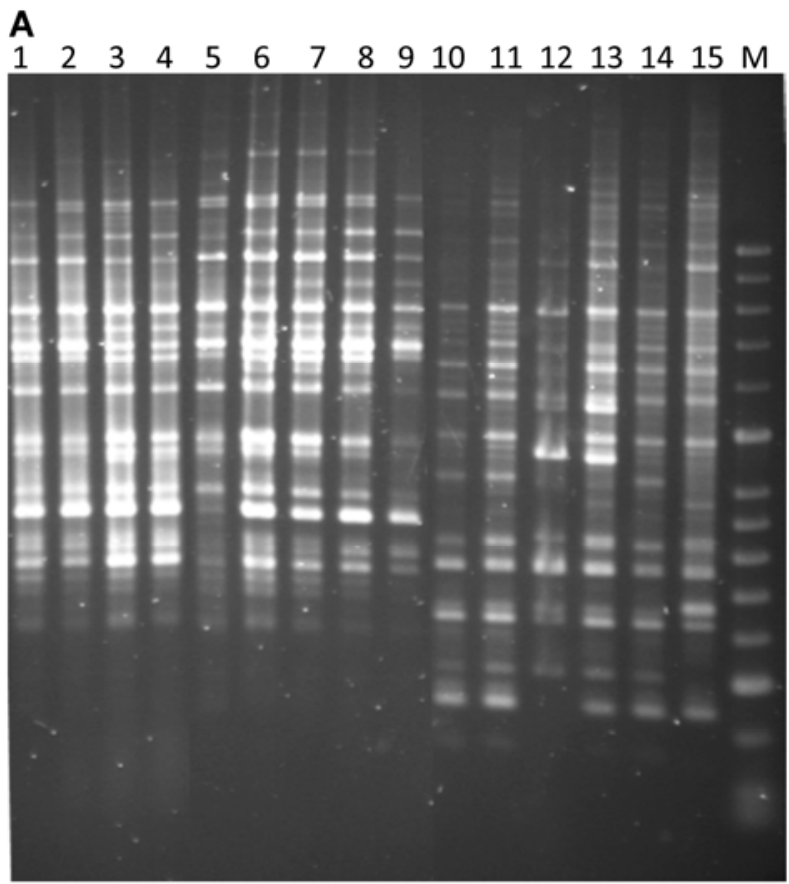

B

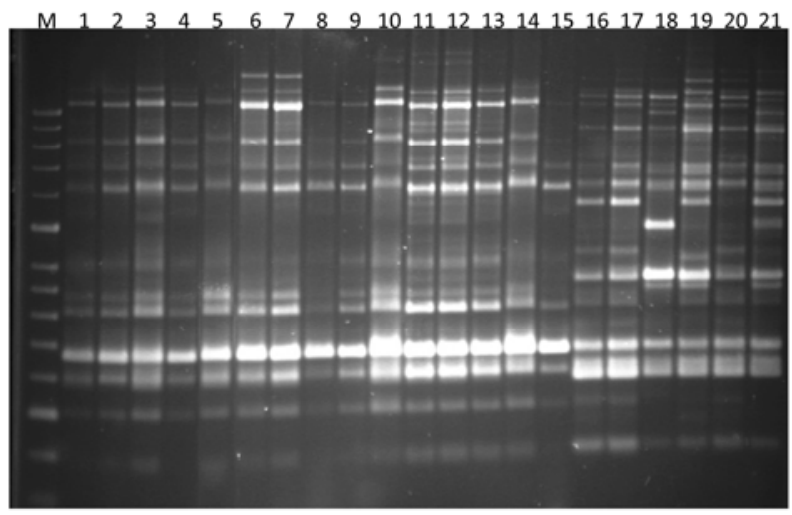

Fig. 4. DNA fingerprints resulting from amplification of Elsinoë australis from Jojoba and citrus with random amplified polymorphic DNA primers. A, OPX-8 amplification: lanes $1-9, E$. australis isolates from Jojoba plantations in southeastern Australia; lanes 10-15, E australis isolates from citrus. B, OPX-12 amplification: lanes 1-15, various $E$. australis isolates from Jojoba plantations in southeastern Australia; lanes $16-21, E$. australis isolates from citrus. $M=$ BioLine Hyper ladder II. 
have been recorded, including $S$. fawcettii var. scabiosa (McAlpine \& Tyron) Jenkins from citrus (23), E. ampelina from grape (16), and a number of species (E. banksiae, E. leucospermi, E. proteae, and $S$. protearum) from the family Proteaceae (19). Although $E$. australis is difficult to differentiate from E. fawcettii, a common pathogen of citrus, based on spore morphology and cultural characteristics (23), the species can be readily differentiated using pathogenicity (23) or molecular techniques $(7,12,21)$. Hyun et al. (12) reported a new pathotype of E. australis from Korea which could only infect the fruit of natsudaidai. This pathotype has not been reported outside of Korea (13). Use of species- and pathotype-specific molecular markers has shown that the isolates from jojoba are closely related to the natsudaidai pathotype. The isolates are not identical, however, because there is polymorphism between the Korean pathotypes and the isolates from jojoba, as demonstrated using the OPX- 8 and 12 RAPD primers. Repeated attempts to inoculate seedlings and both detached leaves and fruit of citrus failed to produce symptoms. The ITS sequencing clearly demonstrates that the fungus isolated from jojoba is distinct from all of these species and appears to be more closely related to the sweet orange pathotype and the natsudaidai pathotype of E. australis reported by Hyun et al. (12). This adds further support to the hypothesis that the jojoba pathotype is genetically similar to the E. australis pathotype from citrus but is a separate and new pathotype.

This study has raised several important questions, including the origin of this pathogen and what threat, if any, it poses to the jojoba and citrus industries of Australia.

\section{Acknowledgments}

This research was supported by the Rural Industries Research and Development Corporation and the Jojoba Growers Association of Australia. We thank R. Hung, G. Nielsen, and A. Sohail for their technical assistance.

\section{Literature Cited}

1. Aburjai, T., and Natsheh, F. M. 2003. Plants used in cosmetics. Phytother. Res. 17:987-1000.

2. Albiston, A., Ash, G. J., Cother, E. J., Bentley, S., and Pattemore, J. 2003. First record of collar rot caused by Fusarium oxysporum in Australian jojoba plantations. Australas. Plant Pathol. 32:319-320.

3. Ash, G. J., Albiston, A., and Cother, E. J. 2005. Aspects of jojoba agronomy and management. Adv. Agron. 85:409-437.

4. Ash, G. J., Cother, E. J., and Albiston, A. 2004. Diseases of jojoba in Australia. (Abstr.) Phytopathology 94:S163.

5. Bitancourt, A. A., and Jenkins, A. E. 1937. Sweet orange scab caused by Elsinoë australis. J. Agric. Res. 54:1-17.

6. Burrows, G. E., Offord, C. A., Meagher, P. F., and Ashton, K. 2003. Axillary meristems and the development of epicormic buds in Wollemi pine (Wollemia nobilis). Ann. Bot. 92:835-844.

7. Chung, K. R. 2011. Elsinoë fawcettii and Elsinoë australis: The fungal pathogens causing citrus scab. Mol. Plant Pathol. 12:123-135.

8. Conde, B. D., Pitkethley, R. N., Smith, E. S. C., Kulkarni, V. J., Thiagalingam, K., Ulyatt, L. I., Connelly, M. I., and Hamilton, D. A. 1997. Identification of mango scab caused by Elsinoë mangiferae in Australia. Australas. Plant Pathol. 26:131-131.
9. Cother, E. J., Noble, D., Peters, B. J., Albiston, A., and Ash, G. J. 2004. A new bacterial disease of jojoba (Simmondsia chinensis) caused by Burkholderia andropogonis. Plant Pathol. 53:129-135.

10. Gentry, H. S. 1958. The natural history of jojoba (Simmondsia chinensis) and its cultural aspects. Econ. Bot. 12:261-295.

11. Hirai, Y., and Tanigawa, T. 1988. Applications of jojoba oil to cosmetic products. J. Am. Oil Chem. Soc. 65:34-34.

12. Hyun, J. W., Peres, N. A., Yi, S. Y., Timmer, L. W., Kim, K. S., Kwon, H. M., and Lim, H. C. 2007. Development of PCR assays for the identification of species and pathotypes of Elsinö̈ causing scab on citrus. Plant Dis. 91:865-870.

13. Hyun, J. W., Yi, S. H., MacKenzie, S. J., Timmer, L. W., Kim, K. S., Kang, S. K., Kwon, H. M., and Lim, H. C. 2009. Pathotypes and genetic relationship of worldwide collections of Elsinö̈ spp. causing scab diseases of citrus. Phytopathology 99:721-728.

14. Kim, K. W., Hyun, J. W., and Park, E. W. 2004. Cytology of cork layer formation of citrus and limited growth of Elsinoë fawcettii in scab lesions. Eur. J. Plant Pathol. 110:129-138.

15. Kumar, S., Tamura, K., and Nei, M. 2004. MEGA3: Integrated software for molecular evolutionary genetics analysis and sequence alignment. Brief. Bioinf. 5:150-163.

16. Magarey, R. D., Emmett, R. W., Margarey, P. A., and Franz, P. R. 1993. Evaluation of control of grapevine anthracnose caused by Elsinoë ampelina by pre-infection fungicides. Australas. Plant Pathol. 22:48-52.

17. Milthorpe, P. L., and Dunstone, R. L. 1989. The potential of jojoba (Simmondsia chinensis) in New South Wales. 1. Growth and yield. Aust. J. Exp. Agric. 29:383-387.

18. Milthorpe, P. L., and Dunstone, R. L. 1989. The potential of jojoba (Simmondsia chinensis) in New South Wales. 2. Some factors affecting yield. Aust. J. Exp. Agric. 29:389-395.

19. Swart, L., Crous, P. W., Kang, J. C., McHau, G. R. A., Pascoe, I., and Palm, M. E. 2001. Differentiation of species of Elsinö̈ associated with scab disease of Proteaceae based on morphology, symptomatology, and ITS sequence phylogeny. Mycologia 93:366-379.

20. Tamura, K., and Nei, M. 1993. Estimation of the number of nucleotide substitutions in the control region of mitochondrial DNA in humans and chimpanzees. Mol. Biol. Evol. 10:512-526.

21. Tan, M. K., Timmer, L. W., Broadbent, P., Priest, M., and Cain, P. 1996 Differentiation by molecular analysis of Elsinö̈ spp. causing scab diseases of citrus and its epidemiological implications. Phytopathology 86:10391044 .

22. Thompson, J. D., Higgins, D. G., and Gibson, T. J. 1994. CLUSTAL W: Improving the sensitivity of progressive multiple sequence alignment through sequence weighting, position-specific gap penalties and weight matrix choice. Nucleic Acids Res. 22:4673-4680.

23. Timmer, L. W., Priest, M., Broadbent, P., and Tan, M. K. 1996. Morphological and pathological characterization of species of Elsinoë causing scab diseases of citrus. Phytopathology 86:1032-1038.

24. White, T. J., Burns, T., Lee, S., and Taylor, J. 1990. Amplification and direct sequencing of fungal ribosomal RNA genes for phylogenetics. In: PCR Protocols: A Guide to Methods and Applications. M. A. Innis, D. H. Gelfand, J. J. Sninsky, and T. J. White, eds. Academic Press, San Diego, CA.

25. Whiteside, J. O. 1978. Pathogenicity of two biotypes of Elsinoë fawcettii to sweet orange and some other cultivars. Phytopathology 68:1128-1131.

26. Woodcock, T. 1983. Pleospora leaf spot of jojoba. Australas. Plant Pathol. 12:14-15.

27. Yermanos, D., and Duncan, C. 1976. Quantitative and qualitative characteristics on jojoba seed. J. Am. Chem. Soc. 53:80-82.

28. Yermanos, D. M. 1975. Composition of jojoba seed during development. J. Am. Oil Chem. Soc. 52:115-117. 